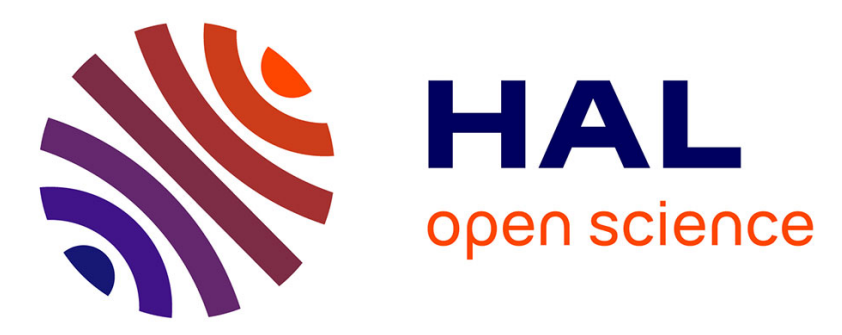

\title{
Multiple post-translational modifications of mouse insulin-like growth factor binding protein-6 expressed in epithelial madin-darby canine kidney cells
}

\author{
L. Shalamanova, B. Kübler, S. Storch, J.-G. Scharf, T. Braulke
}

\section{- To cite this version:}

L. Shalamanova, B. Kübler, S. Storch, J.-G. Scharf, T. Braulke. Multiple post-translational modifications of mouse insulin-like growth factor binding protein-6 expressed in epithelial madindarby canine kidney cells. Molecular and Cellular Endocrinology, 2008, 295 (1-2), pp.18. 10.1016/j.mce.2008.08.034 . hal-00532073

\section{HAL Id: hal-00532073 \\ https://hal.science/hal-00532073}

Submitted on 4 Nov 2010

HAL is a multi-disciplinary open access archive for the deposit and dissemination of scientific research documents, whether they are published or not. The documents may come from teaching and research institutions in France or abroad, or from public or private research centers.
L'archive ouverte pluridisciplinaire HAL, est destinée au dépôt et à la diffusion de documents scientifiques de niveau recherche, publiés ou non, émanant des établissements d'enseignement et de recherche français ou étrangers, des laboratoires publics ou privés. 


\section{Accepted Manuscript}

Title: Multiple post-translational modifications of mouse insulin-like growth factor binding protein-6 expressed in epithelial madin-darby canine kidney cells

Authors: L. Shalamanova, B. Kübler, S. Storch, J.-G. Scharf, T. Braulke

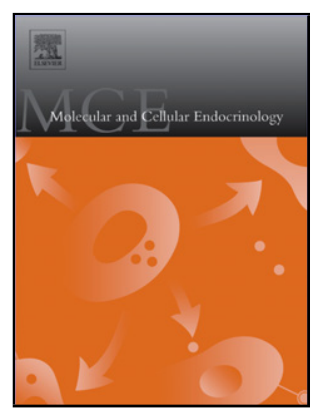

PII: S0303-7207(08)00399-7

DOI: doi:10.1016/j.mce.2008.08.034

Reference: MCE 6971

To appear in: Molecular and Cellular Endocrinology

Received date: 27-1-2008

Revised date: 24-8-2008

Accepted date: $31-8-2008$

Please cite this article as: Shalamanova, L., Kübler, B., Storch, S., Scharf, J.-G., Braulke, T., Multiple post-translational modifications of mouse insulin-like growth factor binding protein-6 expressed in epithelial madin-darby canine kidney cells, Molecular and Cellular Endocrinology (2008), doi:10.1016/j.mce.2008.08.034

This is a PDF file of an unedited manuscript that has been accepted for publication. As a service to our customers we are providing this early version of the manuscript. The manuscript will undergo copyediting, typesetting, and review of the resulting proof before it is published in its final form. Please note that during the production process errors may be discovered which could affect the content, and all legal disclaimers that apply to the journal pertain. 


\title{
MULTIPLE POST-TRANSLATIONAL MODIFICATIONS OF MOUSE INSULIN-LIKE GROWTH FACTOR BINDING PROTEIN-6 EXPRESSED IN EPITHELIAL MADIN- DARBY CANINE KIDNEY CELLS
}

\author{
L. Shalamanova ${ }^{\ddagger \S}$, B. Kübler ${ }^{\ddagger}$, S. Storch ${ }^{\ddagger}$, J.-G. Scharf ${ }^{*}$, T. Braulke ${ }^{\ddagger \pi}$ \\ ‡University Medical Center Hamburg-Eppendorf, Dept. Biochemistry, Children’s \\ Hospital, Martinistrasse 52, D-20246 Hamburg, Germany \\ *Department of Gastroenterology and Endocrinology, Georg-August-University, \\ Robert-Koch-Strasse 40, 37075 Göttingen, Germany \\ \$Present address: Division of Metabolic and Cellular Medicine, University of \\ Liverpool, Duncan Building, Daulby Street, Liverpool L69 3GA, UK
} Running head: Post-translational modifications of mouse IGFBP-6

Address correspondence to: Thomas Braulke, University Medical Center HamburgEppendorf, Dept. Biochemistry, Children's Hospital, Martinistrasse 52, D-20246 Hamburg, Germany Tel. +49 4042803 5947; Fax. +49 4042803 8504;

E-mail: braulke@uke.uni-hamburg.de 
Key words: insulin-like growth factor binding protein-6, ㅇ-glycosylation, posttranslational modification, phosphorylation, sulfation, Madin-Darby canine kidney cells

\section{Abstract}

Insulin-like growth factors (IGFs), IGF receptors and IGF binding proteins (IGFBPs) participate in the regulation of proliferation and differentiation of epithelial cells. Expression of the growth-inhibitory murine IGFBP-6 in epithelial Madin-Darby canine kidney (MDCK) cells followed by 2-D analysis revealed the presence of multiple isoforms. Metabolic labelling experiments showed that several IGFBP-6 isoforms are modified by phosphate and sulfate groups. Expression analysis of mutant IGFBP-6 further demonstrated that serine residue 143 is $\underline{0}$-glycosylated. Substitution of serine 143 by alanine did slightly reduce the preferential sorting of mIGFBP-6 to the apical site in MDCK cells grown on semipermeable filters. Both the presence of multiple and heterogeneously modified isoforms of murine IGFBP-6 in MDCK cells, and the preferential secretion of non-glycosylated IGFBP-6 mutants to the apical side suggest that the major apical sorting signal is the protein moiety. 


\section{Introduction}

The IGFs (IGF-I and IGF-II) are structurally related peptides that play essential roles in regulating metabolic, mitogenic, and differentiation processes by endocrine, autocrine, and paracrine mechanisms (LeRoith et al., 1995). The activity of IGFs is controlled by a family of six high-affinity IGF binding proteins (IGFBP-1 to IGFBP-6), which modulate the availability of IGFs to IGF receptors. In addition, the IGFBPs are involved in the transport and targeting of IGFs to tissues (Cohen, 2006; Jones and Clemmons, 1995; Rajaram et al., 1997). Recent findings have demonstrated that IGFBPs function also as independent growth modulators (Baxter, 2000; Clemmons, 1997; Firth and Baxter, 2002; Scharf et al., 2004). The IGFBPs share a highly conserved structure comprised of three domains. The $\mathrm{N}$ - and C-terminal domains are cysteine-rich and both contribute to the high binding affinity for IGFs. The central regions show low similarity among the different IGFBPs. Post-translational modifications such as proteolytic cleavage, $\underline{N}$ - and $\underline{O}$-glycosylation (Chelius et al., 2002; Firth and Baxter, 1999; Neumann et al., 1998), and phosphorylation (Coverley and Baxter, 1997; Graham et al., 2007; Hoeck and Mukku, 1994; Jones et al., 1993; Jones et al., 1991) have been reported to occur in the central domain (Firth and Baxter, 2002). Both phosphorylation and proteolysis have been shown to affect the IGF binding affinity of IGFBPs (Bunn and Fowlkes, 2003; Jones et al., 1991). In contrast, $\underline{N}$ - and $\underline{O}$-glycosylation appear to be non-essential for binding of IGFBP-3 or IGFBP-6 to IGFs, but have the potential to modulate cell surface binding and binding to extracellular glycosaminoglycans, respectively (Firth and Baxter, 1999; Marinaro et al., 2000b). At present, it is unclear whether post-translational modifications play a role in transport of IGFBPs in the secretory pathway or in differential sorting and 
secretion of IGFBPs in polarized cells (Remacle-Bonnet et al., 1995; Shalamanova et al., 2001).

Among the IGFBPs, IGFBP-6 is unique because of its N-terminal disulfide linkages (Chandrashekaran et al., 2007) and its marked binding preference for IGF-II (Forbes et al., 1990). IGFBP-6 has been considered a potent inhibitor of mitosis which prevents the interaction between IGF-II and the IGF-I receptor most likely by sequestering of IGF-II (Bach et al., 1995; Putzer et al., 1998; Srinivasan et al., 1996). Moreover, IGF-II stimulates the expression of IGFBP-6 indicating a complex regulation of growth (Bach et al., 1997; Claussen et al., 1995). Both human and mouse IGFBP-6 (hIGFBP-6, mIGFBP-6) are $\underline{O}$-glycosylated in a different stochiometry (Bach et al., 1992; Claussen et al., 1995; Neumann et al., 1998). Four

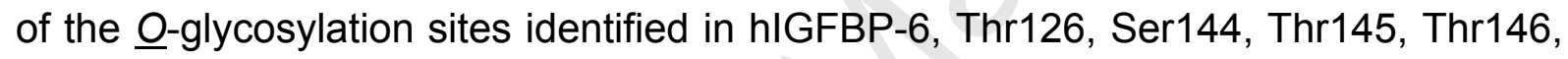
and Ser152, are not conserved in the mIGFBP-6 (Neumann et al., 1998). In vitro studies have reported on a protective role of $\underline{O}$-linked oligosaccharides against proteolysis (Neumann et al., 1998) or clearance of hIGFBP-6 from the circulation (Marinaro et al., 2000a).

In the present study, we have investigated the role of $\underline{O}$-glycosylation as a potential apical sorting signal of mIGFBP-6 expressed in Madin-Darby canine kidney epithelial (MDCK) cells. Additionally, phosphorylation and sulfation of mIGFBP-6 has been identified as post-translational modifications. Expression analysis of mutant mIGFBP-6 demonstrated that substitution of the $\underline{O}$-glycosylation site Ser143 did only slightly impair the preferential sorting of mIGFBP-6 to the apical side. 


\section{Materials and methods}

\subsection{Materials}

$\left[{ }^{35} \mathrm{~S}\right]$-sulfur, $\left[{ }^{33} \mathrm{P}\right]$-orthophosphate, IEF (isoelectric focusing) strips, immobilized $\mathrm{pH}$ gradient (IPG) buffer for hydrating of IEF strips and IEF sample loading, Dry Strip cover Fluid and Rainbow ${ }^{\mathrm{TM}}$-coloured protein molecular-mass marker were purchased from Amersham Pharmacia Biotech Inc. (Freiburg, Germany). Complete-Mini protease inhibitor cocktail was obtained from Roche Diagnostics (Mannheim, Germany), phosphate-free medium and protein A-agarose were from Sigma (Deisenhofen, Germany). Dulbecco's modified Eagel's medium (DMEM) and antibiotics (penicillin /streptomycin) were purchased from Gibco Life Technologies (Karlsruhe, Germany), Trans-Blot nitrocellulose membrane $(0.2 \mu \mathrm{m})$ from Bio-Rad (Munich, Germany). Sulfate-free medium was purchased from Invitrogen $\mathrm{GmbH}$ (Karlsruhe, Germany).

\subsection{Cell culture and selection of stably transfected cell lines}

MDCK cells were grown on $35 \mathrm{~mm}$ dishes (Greiner, Germany) or on 24-mm Transwell polycarbonate filters (Costar, Cambridge, MA), as previously described (Shalamanova et al., 2001). Serum-free medium conditioned for 24-72 hours was collected as described earlier (Shalamanova et al., 2001). Cells were transfected with $10 \mu \mathrm{g}$ of $\mathrm{pBEH}$ plasmid and $1 \mu \mathrm{g}$ of the $\mathrm{pGK}^{\text {Hygro }}$ (hygromycin resistance) plasmid using the calcium phosphate technique. The full-length cDNA of the mIGFBP-6 with $43 \mathrm{bp}$ of the $5^{\prime}$ untranslated region, $229 \mathrm{bp}$ of the $3^{\prime}$ untranslated region and $20 \mathrm{bp}$ of polyA was cloned into pBEH expression vector (Schuller et al., 1994). Selection of cells resistant to hygromycin was initiated 16 hours after transfection. Hygromycinresistant colonies were isolated and screened for mIGFBP-6 secretion into 
conditioned medium by IGF-II ligand blotting (Kubler et al., 2002) with monobiotinylated IGF-II (bIGF-II; GroPep, Adelaide, Australia), or Western blotting using goat anti-mouse IGFBP-6 antibody (Santa Cruz Biotechnology, Santa Cruz, CA). The polypeptides were visualized using the SuperSignal enhanced chemiluminescence detection system (Pierce Chemical, Rockford, IL).

\subsection{Generation of mutant mIGFBP-6}

Human IGFBP-6 is $\underline{O}$-glycosylated at Thr126, Ser144, Thr145, Thr146, and Ser152. Only one of these residues (Ser144) is conserved in mIGFBP6 and corresponds to Ser143 (Neumann et al., 1998) which was substituted with alanine (A143) by PCRbased site directed mutagenesis using Pfu-Turbo ${ }^{\text {TM }}$-DNA-Polymerase (Stratagene, La Jolla, USA). As control, non-conserved residue 126 in mIGFBP-6 was substituted by alanine (A126) alone or in combination with $A 143$ (A126/143). The mutants mIGFBP-6 A126, A143 and A126/143 were stably expressed in MDCK cells.

\subsection{Non-reducing two-dimensional (2D) electrophoresis}

Broad ( $\mathrm{pH}$ 3-10) or narrow ( $\mathrm{pH}$ 6-11) range IPG strips (Amersham Biosciences) were used in $2 \mathrm{D}$ electrophoresis. The strips were rehydrated with $0.2 \mathrm{ml}$ of rehydration buffer containing $8 \mathrm{M}$ urea, 2\% (w/v) Chaps and $0.5 \%(\mathrm{v} / \mathrm{v})$ IPG buffer at room temperature for 16 hours, as recommended by the manufacturer. Proteins precipitated with acetone from conditioned media (Shalamanova et al., 2001) were resuspended in $0.1 \mathrm{ml}$ of rehydration buffer and applied on IPG gels. Isoelectric focusing was carried out for 18,100 Volt-hours $(200 \mathrm{~V} \times 30 \mathrm{~min}, 3000 \mathrm{~V} \times 6 \mathrm{~h})$ at $20^{\circ} \mathrm{C}$. The IPG strips were then equilibrated in buffer containing $50 \mathrm{mM} \mathrm{Tris} / \mathrm{HCl} \mathrm{pH}$ 8.8, $6 \mathrm{M}$ urea, 30\% (v/v) glycerol, $2 \%(\mathrm{w} / \mathrm{v})$ SDS, and $0.01 \%$ bromphenol blue. The 
equilibrated IPG strips were subjected to $12.5 \%$ non-reducing SDS-PAGE, and blotted onto nitrocellulose membranes.

\subsection{Metabolic labelling}

Cells grown on $60 \mathrm{~mm}$ dishes were incubated for 2 hours with sulfate-free or phosphate-free medium supplemented with $0.05 \%$ bovine serum albumin (BSA). The media were then removed and cells were labelled with $150 \mu \mathrm{Ci}\left[{ }^{35} \mathrm{~S}\right]$-sulfur or $100 \mu \mathrm{Ci}$ $\left[{ }^{33} \mathrm{P}\right]$-orthophosphate for 20 hours at $37^{\circ} \mathrm{C}$. The media were collected, centrifuged and subjected to acetone precipitation. The precipitates were boiled in non-reducing loading buffer and centrifuged. The supernatants were subjected to SDS-PAGE followed by fluorography. 


\section{Results}

\subsection{Expression of mIGFBP-6 in MDCK cells}

MDCK cells transfected either with the pGK vector alone or with $\mathrm{pGK}$ and $\mathrm{pBEH}$ vector containing mIGFBP-6 cDNA produced several hygromycin resistant clones. In conditioned media of non-transfected or vector-transfected MDCK cells no IGFBP polypeptides were detectable by biotinylated IGF-II (Fig. 1A) which allows the detection of overexpressed mIGFBP-6 but not of endogenous canine IGFBPs secreted by MDCK cells (Shalamanova et al., 2000). In contrast, a broad band with apparent molecular mass between 26 and $27.5 \mathrm{kDa}$ was identified in conditioned media of MDCK cells transfected with the mIGFBP-6 cDNA. Western immunoblots using an antibody specific for mIGFBP-6 confirmed the presence of mIGFBP-6 (Fig. 1B). Since no apparent differences were observed in conditioned media from nontransfected and vector-transfected MDCK cells either by bIGF-II ligand blotting or Western blotting, media from non-transfected cells were used as negative control in all further experiments.

\subsection{Transfected MDCK cells secrete multiple mIGFBP-6 isoforms}

According to the SWISS-PROT database (accession number P47880), the molecular mass of the unprocessed mIGFBP-6 precursor is $25.4 \mathrm{kDa}$. The discrepancy between the molecular mass of the mIGFBP- 6 precursor and the $26,26.5$ and 27.5 kDa mIGFBP-6 isoforms secreted by MDCK mIGFBP-6 expressing cells (Fig. 1) suggested the presence of post-translational modifications. To characterize the mIGFBP-6 isoforms, conditioned media from MDCK cells overexpressing mIGFBP-6 were subjected to non-reducing 2D-electrophoresis (Fig. 2B). Biotinylated IGF-II ligand blotting detected ten different mIGFBP-6 spots that were grouped according to 
the apparent molecular mass (spots $1,2,4,5$, and 7 with $27.5 \mathrm{kDa}$, spots 6,8 , 9, and 10 with $26.5 \mathrm{kDa}$, and spot 3 with $26 \mathrm{kDa}$ ), and according to the pl (pl 5.5-7: spots 1 and 2, pl 7.5-8: spots 3, 4, 5, and 6, and pl 9-9.7: spots 7, 8, 9, and 10). No IGFBP-6 spots were detected in conditioned media from non-transfected MDCK cells (Fig. 2A).

\subsection{Phosphorylated mIGFBP-6 isoforms}

To examine whether mIGFBP-6 is phosphorylated, MDCK cells expressing mIGFBP6 were metabolically labelled for 20 hours with $\left[{ }^{33} \mathrm{P}\right]$-orthophosphate followed by acetone precipitation of secreted proteins from the media, 2D-electrophoresis and fluorography. Four phosphorylated mIGFBP-6 forms (spots 1, 2, 8, and 10) were detectable in media of mIGFBP-6 expressing cells (Fig. 3B) which were absent in media of $\left[{ }^{33} \mathrm{P}\right]$-orthophosphate-labelled control MDCK cells (Fig. 3A). A series of seven phosphorylated polypeptides with molecular masses $>30 \mathrm{kDa}$ (designated from a to g) were present both in control and mIGFBP-6 containing media indicating that they are not related to mIGFBP-6.

\subsection{Sulfated mIGFBP-6 isoforms}

The 2D-electrophoretic analysis of media collected from control and mIGFBP-6 expressing MDCK cells labelled with $\left[{ }^{35}\right.$ S]-sulfur revealed the presence of three unique $\left[{ }^{35} \mathrm{~S}\right]$-sulfate-labelled polypeptide in media from mIGFBP-6 expressing MDCK cells (indicated by arrows matching spots 5,8 , and 10 in Fig. 4B). $\left[{ }^{35}\right.$ S]-sulfated polypeptides unrelated to mIGFBP-6 with molecular masses $>30 \mathrm{kDa}$ were found in both media and are labelled with $\mathrm{h}$ to $\mathrm{q}$.

\subsection{O-glycosylation of mIGFBP-6}


Human IGFBP-6 was reported to be $\underline{O}$-glycosylated at Thr126, Ser144, Thr145, Thr146, and Ser152. Only one of these amino acids is conserved in mIGFBP6, i.d. Ser143 (Neumann et al., 1998). To examine whether Ser143 is $\underline{O}$-glycosylated this residue was substituted with alanine (A143). The mutant, mIGFBP-6 A143, was stably expressed in MDCK cells. Conditioned media were collected after 48 hours from non-transfected MDCK cells, and cells expressing wildtype mIGFBP-6 or mIGFBP-6 A143 and analyzed by Western blotting. Fig.5 shows that the electrophoretic mobility of mutant mIGFBP-6 A143 was slightly increased by $1 \mathrm{kDa}$ compared with wildtype mIGFBP-6. This indicates that Ser143 in mIGFBP-6 is $\underline{0}-$ glycosylated.

When conditioned media were analyzed by $2 \mathrm{D}$-electrophoresis and bIGF-II ligand blotting using narrow range $\mathrm{pl}$ strips ( $\mathrm{pl}$ 6-11) to increase the resolution in the basic $\mathrm{pl}$ range, the wildtype mIGFBP- 6 spots 1 and 2 identified by the broad range pl strips (Fig. 2) were not longer detectable (Fig. 6). While the reason for the disappearance of spots repeatedly proven is unclear, it is likely that spots 1 and 2 are not visible in the pl 6-11 strips due to their low pl (5.5 and 6.5, respectively). The narrow range pl 6-11 strips, however, revealed the presence of two new wildtype mIGFBP-6 spots (spots 11 and 12) able to bind bIGF-II in the very basic end of the pl strips (Fig. 6). The 2D-electrophoretic pattern of mutant mIGFBP-6 A143 demonstrated the absence of spots 6,11 , and 12 . In addition, a new spot not present in media from wildtype mIGFBP-6 expressing MDCK cells was detected in mIGFBP-6 A143 (indicated with an asterisk) with apparent molecular mass of $26.5 \mathrm{kDa}$ (Fig. 6). Of note, the electrophoretic mobility of the mutant mIGFBP-6 A143 was slightly higher than that of the wildtype mIGFBP-6 (Fig. 6). These data suggest that three bIGF-II binding mIGFBP-6 isoforms (spot 6, 11, and 12) are $\underline{0}$-glycosylated at Ser143 in addition to other post-translational modifications. Of note, the disappearance of spots, i.e. the 
loss in capability to bind the IGF-II ligand, due to the mutation of an $\underline{O}-$ glycosylation site, is a strong argument that in these isoforms the glycosylation site is used. However, we cannot exclude that more mIGFBP-6 isoforms are glycosylated at Ser143 which cannot be detected by bIGF-II ligand blotting e.g due to other posttranslational modifications.

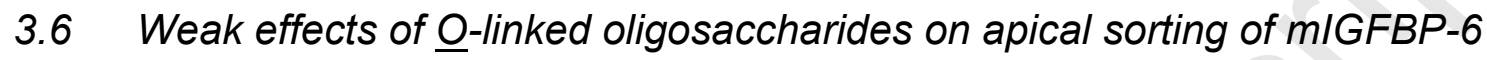

The majority of endogenous IGFBPs are sorted to the apical medium of polarised MDCK cells (Remacle-Bonnet et al., 1995; Shalamanova et al., 2001). Because $\underline{\text { O- }}$ glycosylation has been implicated in the sorting of proteins in polarized cells (Yeaman et al., 1997), we analyzed the apical-basolateral sorting pattern of wildtype, mutant mIGFBP-6 A126, A143, and the double mutant mIGFBP-6 A126/143 in polarized MDCK cells. Conditioned media from cells grown on polycarbonate filters were collected after 48 hours and subjected to SDS-PAGE and bIGF-II ligand blotting. The electrophoretic mobility of the mutant mIGFBP-6 A126 form was not altered in comparison with wildtype mIGFBP-6 whereas bot mutants A143 and A126/143 exhibited reduced molecular masses (see also Fig. 5). About 74 and $26 \%$ of the total secreted wildtype or mutant mIGFBP-6 A126 were found in the apical and basolateral media, respectively, as estimated by densitometry (Fig. 7). In contrast, the amount of apically sorted mutant mIGFBP-6 A143 alone or in combination with Ala126 was slightly reduced to 64 or $65 \%$ of total, respectively. These data indicate i) that Ser126 is not used as $\underline{O}$-glycosylation site and ii) that the majority of the

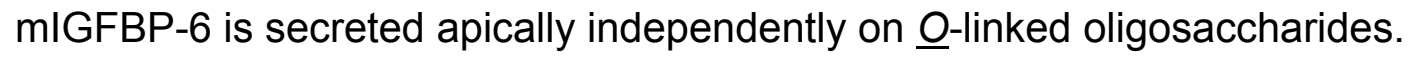




\section{Discussion}

In this study, we have investigated the post-translational modifications of the growth regulating murine IGF binding protein-6. The results show that the mIGFBP-6 overexpressed and secreted by canine epithelial MDCK cells is $\underline{O}$-glycosylated, phosphorylated, and may be equipped with sulfate residues. The preferential targeting of mIGFBP-6 to the apical side of polarized MDCK cells, however, was only slightly affected by substitution of the single $\underline{0}$-glycosylation site at serine residue 143.

As reported previously, biotinylated IGF-II binds to human and murine IGFBPs but is incapable of binding to canine IGFBPs (Shalamanova et al., 2000). In this study, we used this characteristic of the bIGF-II to specifically detect mIGFBP-6 overexpressed in the canine MDCK cells. 2D electrophoresis and bIGF-II ligand blotting of media of MDCK cells stably expressing mIGFBP-6 revealed the synthesis and secretion of multiple mIGFBP-6 isoforms. These multiple isoforms appear to caused by various post-translational modifications. $\mathrm{N}$-glycosylation is an unlikely modification of mIGFBP-6 because of the lack of $\mathrm{N}$-glycosylation consensus sequences. Thus far, the only post-translational modifications described for IGFBP-6 have been $\underline{O}$-glycosylation and microheterogeneity of the amino acid sequence (Bach, 1999; Bach, 2005).

Labelling of mIGFBP-6 overexpressing MDCK cells with $\left[{ }^{33} \mathrm{P}\right]$-orthophosphate or $\left[{ }^{35} \mathrm{~S}\right]$-sulfur, followed by $2 \mathrm{D}$-electrophoresis showed that at least four of the mIGFBP-6 isoforms are phosphorylated and three are sulfated (Table 1). Interestingly, two of the four phosphorylated isoforms were sulfated as well. Among the IGFBPs, phosphorylation has been described only for IGFBP-1 (at Ser101, Ser119, and Ser169), IGFBP-3 (at Ser111, and Ser113), and IGFBP-5 (at Ser96, 
and Ser248) (Hwa et al., 1999; Graham et al., 2007). The hIGFBP-6 expressed in CHO-cells has been repoted not be phosphorylated (Neumann et al., 1998). Among the 10 potential serine phosphorylation sites in mIGFBP-6 predicted by the NetPhos 2.0 program, Ser112 may represent a phosphorylation site due to sequence homologies with the phosphorylated Ser101 in hIGFBP-1 (PSEE; Jones et al., 1993). In sera of healthy individuals, IGFBP-1 circulates as a highly phosphorylated form, whereas non-phosphorylated variants are markedly increased in fetal serum and during pregnancy (Westwood et al., 1994). Phosphorylated IGFBP-1 exhibits a higher affinity for IGF-I than non-phosphorylated IGFBP-1 and inhibits the biological effects of IGF-I (Jones et al., 1993; Jones et al., 1991; Scharf et al., 2004; Westwood et al., 1997). In contrast, phosphorylation of IGFBP-3 does not appear to influence its binding to IGFs (Hoeck and Mukku, 1994). The importance of phosphorylation for the function of IGFBP-6, the sites and stochiometry of phosphorylation, the kinases involved and their regulation remain a matter of further investigations.

There is a lack of information on sulfation of IGFBP-6 and its physiological significance. Sulfation of proteins can occur on tyrosine residues and $\underline{O}$-glycans. Whereas sulfation of tyrosine residues is a common post-translational modification of secretory proteins (Monigatti et al., 2006) no defined consensus sequence for tyrosine sulfation is evident. Examination, however, of the local sequences at known sites of tyrosine sulfation reveals acidic amino acids around the target tyrosine, in particular in the immediate $\mathrm{N}$-terminal position -1 (Monigatti et al., 2006). In mIGFBP-6 none of the tyrosine residues, Tyr75, Tyr184, and Tyr194, are flanked by acidic amino acids. Thus, the identification of sulfation sites in mIGFBP-6 remains to be elucidated. Sulfation appears to play a role in proper cellular processing and biological activity of a number of proteins (Vishnuvardhan and Beinfeld, 2000). Thus, it has been shown that elimination of a tyrosine sulfation site by site-directed 
mutagenesis results in a transport retardation of the yolk protein in $\underline{D}$. melanogaster from trans-Golgi network to the cell surface (Friederich et al., 1988). Nevertheless, the significance and function of sulfated tyrosine residues as sorting signals in mammalian cells still remain to be investigated.

Another post-translational modification, which may contribute to the molecular heterogeneity of mIGFBP-6 is a microheterogeneity of the amino acid sequence, e.g., $80 \%$ of the hIGFBP- 6 overexpressed in $\mathrm{CHO}$ cells starts at Arg28 and lacks the C-terminal Gly240, and 18\% commences at Leu26 (Neumann et al., 1998). Interestingly, non-glycosylated hIGFBP-6 representing about $3 \%$ of the total amount of hIGFBP-6 was found to be not N-terminally truncated (Neumann et al., 1998).

mIGFBP-6 secreted by MDCK cells reveals the presence of isoforms with $\mathrm{pl}$ values ranging between 5.5 and 10.7. Human IGFBP-6 isolated from serum and cerebrospinal fluid represents five isoforms with the pl range of between 4.8 and 5.8 (Weber et al., 1999). The theoretical pl value of IGFBP-6 is 8.62 according to the ExPASy proteomics server of the Swiss Institute of Bioinformatics (http://au.expasy.org; access number P47880). The discrepancy between the data presented here and the results by Weber et al. may be due to species differences and sample preparation. Additionally, it is likely that not all hIGFBP-6 forms in the serum have been recognized and precipitated by the antiserum used by Weber and colleagues (Weber et al., 1999).

In epithelial cells, the plasma membrane proteins and secretory proteins are sorted in a polarized manner either to the apical or the basolateral surface. While the signals and mechanisms responsible for sorting of membrane proteins are well documented (Rodriguez-Boulan et al., 2004), little is known about the polarized targeting of secretory proteins. Both $\underline{N}$ - and $\underline{O}$-linked oligosaccharides of proteins, as well as linear glycosaminoglycans and their extent of sulfation appear to exhibit 
apical sorting information (Kolset et al., 1999; Scheiffele et al., 1995; Spodsberg et al., 2001; Vuong et al., 2006). The endogenous IGFBPs in MDCK cells are preferentially secreted to the apical side of the cells, whereas IGFBP-4 and IGFBP-6 proteases are delivered to the basolateral medium (Shalamanova et al., 2001). We examined whether $\underline{O}$-glycosylation at Ser143 is essential for apical sorting of mIGFBP-6 in polarized epithelial cells. The substitution of Ser143 with alanine resulted in a slight reduction of the apical sorting efficiency of mIGFBP-6 by approximately $10 \%$ compared with wildtype mIGFBP-6 expressing MDCK cells. Due to the conserved nature of $\underline{O}$-glycosylated serine residues in hIGFBP-6 our results confirmed that Ser143 in mIGFBP-6 represents the the major oligosaccharide $\underline{O}-$ glycosylation site. However, we cannot exclude that mIGFBP-6 contain additional single or multiple $\underline{O}$-linked monosaccharides which may contribute both to mIGFBP-6 microheterogeneity and sorting efficiency. The data and the complex posttranslational modifications in the individual isoforms suggest that the majority of mIGFBP-6 is transported apically by signals encoded in the protein moiety.

Taken together, we have identified the major site for O-glycosylation in mIGFBP-6 and two novel post-translational modifications, phosphorylation and sulfation. These post-translational modifications appear to contribute to the heterogeneity of different isoforms and may be important for the directional transport of mIGFBP-6 in polarized cells. The coordinated expression, transport and secretion of different components of the IGF axis appear to be necessary for the maintenance of the proliferative state and the initiation of differentiation of epithelial cells. 


\section{Acknowledgements}

We are grateful to Cyrilla Cole-Maelicke for help with the manuscript. This research was supported by grants from the Deutsche Forschungsgemeinschaft (GRK 335). The authors are indebted to Dr. Alwin Schuller (Department of Neuroscience and Cell Biology, University of Medicine and Dentistry New Jersey, USA) for providing the fulllength cDNA of the mIGFBP-6. 


\section{References}

Bach, L.A., 1999. Insulin-like growth factor binding protein-6: the "forgotten" binding protein? Horm Metab Res. 31, 226-234.

Bach, L.A., 2005. IGFBP-6 five years on; not so 'forgotten'? Growth Horm IGF Res. $15,185-192$.

Bach, L.A., Leeding K.S., Leng S.L., 1997. Regulation of IGF-binding protein- 6 by dexamethasone and IGFs in PC12 rat phaeochromocytoma cells. J Endocrinol. 155, 225-232.

Bach, L.A., Salemi R., Leeding K.S., 1995. Roles of insulin-like growth factor (IGF) receptors and IGF-binding proteins in IGF-II-induced proliferation and differentiation of L6A1 rat myoblasts. Endocrinology. 136, 5061-5069.

Bach, L.A., Thotakura N.R., Rechler M.M., 1992. Human insulin-like growth factor binding protein-6 is O-glycosylated. Biochem Biophys Res Commun. 186, 301-307.

Baxter, R.C., 2000. Insulin-like growth factor (IGF)-binding proteins: interactions with IGFs and intrinsic bioactivities. Am J Physiol Endocrinol Metab. 278, E967976.

Bunn, R.C., Fowlkes J.L., 2003. Insulin-like growth factor binding protein proteolysis. Trends Endocrinol Metab. 14, 176-181.

Chandrashekaran, I.R., Yao S., Wang C.C., Bansal P.S., Alewood P.F., Forbes B.E., Wallace J.C., Bach L.A., Norton R.S., 2007. The N-Terminal Subdomain of Insulin-like Growth Factor (IGF) Binding Protein 6. Structure and Interaction with IGFs. Biochemistry. 46, 3065-3074.

Chelius, D., Wu S.L., Bondarenko P.V., 2002. Identification of N-linked oligosaccharides of rat insulin-like growth factor binding protein-4. Growth Horm IGF Res. 12, 169-177.

Claussen, M., Buergisser D., Schuller A.G., Matzner U., Braulke T., 1995. Regulation of insulin-like growth factor (IGF)-binding protein-6 and mannose 6phosphate/IGF-II receptor expression in IGF-IL-overexpressing NIH 3T3 cells. Mol Endocrinol. 9, 902-912.

Clemmons, D.R., 1997. Insulin-like growth factor binding proteins and their role in controlling IGF actions. Cytokine Growth Factor Rev. 8, 45-62.

Cohen, P., 2006. Overview of the IGF-I system. Horm Res. 65 Suppl 1, 3-8.

Coverley, J.A., Baxter R.C., 1997. Phosphorylation of insulin-like growth factor binding proteins. Mol Cell Endocrinol. 128, 1-5.

Firth, S.M., Baxter R.C., 1999. Characterisation of recombinant glycosylation variants of insulin-like growth factor binding protein-3. J Endocrinol. 160, 379-387.

Firth, S.M., Baxter R.C., 2002. Cellular actions of the insulin-like growth factor binding proteins. Endocr Rev. 23, 824-854.

Forbes, B., Ballard F.J., Wallace J.C., 1990. An insulin-like growth factor-binding protein purified from medium conditioned by a human lung fibroblast cell line (He[39]L) has a novel N-terminal sequence. J Endocrinol. 126, 497-506.

Friederich, E., Fritz H.J., Huttner W.B., 1988. Inhibition of tyrosine sulfation in the trans-Golgi retards the transport of a constitutively secreted protein to the cell surface. J Cell Biol. 107, 1655-1667.

Graham, M.E., Kilby, D.M., Firth, S.M., Robinson, P.J., Baxter, R.C., 2007. The in vivo phosphorylation and glycosylation of human insulin-like growth factorbinding protein-5. Mol Cell Proteom. 6, 1392-1405. 
Hoeck, W.G., Mukku V.R., 1994. Identification of the major sites of phosphorylation in IGF binding protein-3. J Cell Biochem. 56, 262-273.

Hwa, V., Oh Y., Rosenfeld R.G., 1999. The insulin-like growth factor-binding protein (IGFBP) superfamily. Endocr Rev. 20, 761-787.

Jones, J.I., Busby W.H., Jr., Wright G., Smith C.E., Kimack N.M., Clemmons D.R., 1993. Identification of the sites of phosphorylation in insulin-like growth factor binding protein-1. Regulation of its affinity by phosphorylation of serine 101 . J Biol Chem. 268, 1125-1131.

Jones, J.I., Clemmons D.R., 1995. Insulin-like growth factors and their binding proteins: biological actions. Endocr Rev. 16, 3-34.

Jones, J.I., D'Ercole A.J., Camacho-Hubner C., Clemmons D.R., 1991. Phosphorylation of insulin-like growth factor (IGF)-binding protein 1 in cell culture and in vivo: effects on affinity for IGF-I. Proc Natl Acad Sci U S A. 88, 7481-7485.

Kolset, S.O., Vuong T.T., Prydz K., 1999. Apical secretion of chondroitin sulphate in polarized Madin-Darby canine kidney (MDCK) cells. J Cell Sci. 112 ( Pt 11), 1797-1801.

Kubler, B., Draeger C., John H., Andag U., Scharf J.G., Forssmann W.G., Braulke T., Standker L., 2002. Isolation and characterization of circulating fragments of the insulin-like growth factor binding protein-3. FEBS Lett. 518, 124-128.

LeRoith, D., Werner H., Beitner-Johnson D., Roberts C.T., Jr., 1995. Molecular and cellular aspects of the insulin-like growth factor I receptor. Endocr Rev. 16, 143-163.

Marinaro, J.A., Casley D.J., Bach L.A., 2000a. O-glycosylation delays the clearance of human IGF-binding protein-6 from the circulation. Eur J Endocrinol. 142, 512-516.

Marinaro, J.A., Neumann G.M., Russo V.C., Leeding K.S., Bach L.A., 2000b. Oglycosylation of insulin-like growth factor (IGF) binding protein-6 maintains high IGF-II binding affinity by decreasing binding to glycosaminoglycans and susceptibility to proteolysis. Eur J Biochem. 267, 5378-5386.

Monigatti, F., Hekking, B., Steen, H., 2006. Protein sulfation analysis-a primer. Biochim Biophys Acta. 1764, 1904-1913.

Neumann, G.M., Marinaro J.A., Bach L.A., 1998. Identification of O-glycosylation sites and partial characterization of carbohydrate structure and disulfide linkages of human insulin-like growth factor binding protein 6 . Biochemistry. 37, 6572-6585.

Putzer, P., Breuer P., Gotz W., Gross M., Kubler B., Scharf J.G., Schuller A.G., Hartmann H., Braulke T., 1998. Mouse insulin-like growth factor binding protein-6: expression, purification, characterization and histochemical localization. Mol Cell Endocrinol. 137, 69-78.

Rajaram, S., Baylink D.J., Mohan S., 1997. Insulin-like growth factor-binding proteins in serum and other biological fluids: regulation and functions. Endocr Rev. 18, 801-831.

Remacle-Bonnet, M., Garrouste F., el Atiq F., Marvaldi J., Pommier G., 1995. Cell polarity of the insulin-like growth factor system in human intestinal epithelial cells. Unique apical sorting of insulin-like growth factor binding protein-6 in differentiated human colon cancer cells. J Clin Invest. 96, 192-200.

Rodriguez-Boulan, E., Musch A., Le Bivic A., 2004. Epithelial trafficking: new routes to familiar places. Curr Opin Cell Biol. 16, 436-442.

Scharf, J.G., Dombrowski F., Novosyadlyy R., Eisenbach C., Demori I., Kubler B., Braulke T., 2004. Insulin-like growth factor (IGF)-binding protein-1 is highly 
induced during acute carbon tetrachloride liver injury and potentiates the IGFI-stimulated activation of rat hepatic stellate cells. Endocrinology. 145, 34633472.

Scheiffele, P., Peranen J., Simons K., 1995. N-glycans as apical sorting signals in epithelial cells. Nature. 378, 96-98.

Schuller, A.G., Groffen C., van Neck J.W., Zwarthoff E.C., Drop S.L., 1994. cDNA cloning and mRNA expression of the six mouse insulin-like growth factor binding proteins. Mol Cell Endocrinol. 104, 57-66.

Shalamanova, L., Kubler B., Scharf J.G., Braulke T., 2000. Ligand blotting: iodinated vs biotinylated IGF. Growth Horm IGF Res. 10, 294.

Shalamanova, L., Kubler B., Scharf J.G., Braulke T., 2001. MDCK cells secrete neutral proteases cleaving insulin-like growth factor-binding protein-2 to -6. Am J Physiol Endocrinol Metab. 281, E1221-1229.

Spodsberg, N., Jacob R., Alfalah M., Zimmer K.P., Naim H.Y., 2001. Molecular basis of aberrant apical protein transport in an intestinal enzyme disorder. J Biol Chem. 276, 23506-23510.

Srinivasan, N., Edwall D., Linkhart T.A., Baylink D.J., Mohan S., 1996. Insulin-like growth factor-binding protein-6 produced by human PC-3 prostate cancer cells: isolation, characterization and its biological action. J Endocrinol. 149, 297-303.

Vishnuvardhan, D., Beinfeld M.C., 2000. Role of tyrosine sulfation and serine phosphorylation in the processing of procholecystokinin to amidated cholecystokinin and its secretion in transfected AtT-20 cells. Biochemistry. 39, 13825-13830.

Vuong, T.T., Prydz K., Tveit H., 2006. Differences in the apical and basolateral pathways for glycosaminoglycan biosynthesis in Madin-Darby canine kidney cells. Glycobiology. 16, 326-332.

Weber, M.M., Spottl G., Gossl C., Engelhardt D., 1999. Characterization of human insulin-like growth factor-binding proteins by two-dimensional polyacrylamide gel electrophoresis and Western ligand blot analysis. J Clin Endocrinol Metab. 84, 1679-1684.

Westwood, M., Gibson J.M., Davies A.J., Young R.J., White A., 1994. The phosphorylation pattern of insulin-like growth factor-binding protein-1 in normal plasma is different from that in amniotic fluid and changes during pregnancy. $J$ Clin Endocrinol Metab. 79, 1735-1741.

Westwood, M., Gibson J.M., White A., 1997. Purification and characterization of the insulin-like growth factor-binding protein-1 phosphoform found in normal plasma. Endocrinology. 138, 1130-1136.

Yeaman, C., Le Gall A.H., Baldwin A.N., Monlauzeur L., Le Bivic A., RodriguezBoulan E., 1997. The O-glycosylated stalk domain is required for apical sorting of neurotrophin receptors in polarized MDCK cells. J Cell Biol. 139, 929-940. 


\section{Figure legends}

Fig. 1. bIGF-II ligand blot (A) and IGFBP-6 immunoblot (B) of conditioned media from mIGFBP-6 overexpressing MDCK cells. After incubation for 48 hours, conditioned media from MDCK (-), MDCK pGK (vector) or mIGFBP-6 overexpressing MDCK cells were precipitated in acetone and subjected to $12.5 \%$ SDS-PAGE. IGFBPs were detected by ligand blotting using bIGF-II as tracer and by Western blotting using a mouse IGFBP-6-specific antibody $(n=6)$. The positions of the molecular mass standards (in $\mathrm{kDa}$ ) are indicated on the left.

Fig. 2. bIGF-II ligand blot of mIGFBP-6 isoforms. Conditioned media (48 hours) from non-transfected MDCK (A) or mIGFBP-6 overexpressing MDCK (B) cells were precipitated in acetone and subjected to non-reducing 2D-electrophoresis using pl 310 IPG strips. Conditioned media from mIGFBP-6 overexpressing MDCK cells were used as positive control (Co). Presence of IGFBPs was analyzed by bIGF-II ligand blotting $(n=4)$. The positions of the molecular mass standards are indicated.

Fig. 3. Phosphorylated mIGFBP-6 isoforms. Non-transfected MDCK cells (A) or mIGFBP-6 overexpressing MDCK cells (B) grown on plastic dishes were labelled with $\left[{ }^{33} \mathrm{P}\right]$-orthophosphate for $20 \mathrm{~h}$. Three hundred $\mu \mathrm{l}$ of conditioned media were precipitated in acetone, subjected to 2 D-electrophoresis as described in the legend of Fig. 2, and detected by fluorography. Arrows indicate four mIGFBP-6 phosphorylated isoforms with apparent molecular masses of $27.5 \mathrm{kDa}$ (spot 1, and 2) and $26.5 \mathrm{kDa}$ (spot 8 , and 10). Proteins unrelated to phosphorylated mIGFBP-6 are labelled with a to $\mathrm{g}$. The fluorograph shown is representative of 3 experiments. 
Fig. 4. Sulfation of mIGFBP-6 in MDCK cells. Three hundred $\mu$ of conditioned media from non-transfected MDCK cells (A) or mIGFBP-6 overexpressing MDCK cells (B) radiolabelled with $\left[{ }^{35} \mathrm{~S}\right]$-sulfur were precipitated in acetone and subjected to nonreducing 2D-electrophoresis and detected by fluorography. Arrows indicate three sulfated isoforms of mIGFBP-6 (spot 5, 8, and 10). Spots of sulfated proteins unrelated to mIGFBP-6 are labelled with $\mathrm{h}$ to $\mathrm{q}$. The experiment was repeated twice.

Fig. 5. Expression of mutant mIGFBP-6 A143. Conditioned media (24 hours) of MDCK cells (-), wildtype (WT) and mutant mIGFBP-6 A143 overexpressing MDCK cells were analysed by Western blotting using mIGFBP-6-specific antibodies $(n=6)$.

Fig. 6. Two-dimensional analysis of mutant mIGFBP-6 S143A. Media from wildtype mIGFBP-6 secreting MDCK cells or from mutant mIGFBP-6 S143A expressing MDCK cells were collected after $48 \mathrm{~h}$ of culture. $300 \mu \mathrm{l}$ conditioned media were precipitated in acetone and subjected to 2D-electrophoresis using with narrow pl 611 IPG strips. mIGFBP-6 spots were detected by bIGF-II ligand blotting. A new spot appearing in the media from mutant mIGFBP-6 A143 forms is marked with an asterisk. Of note, the two acidic slowly migrating spots in the lower mIGFBP-6 A143 blot appear to be unspecific and not found in replicate experiments $(n=3)$.

Fig. 7. Polarized sorting of mutant mIGFBP-6 in MDCK cells. Apical (a) and basolateral (b) media from vector-transfected (vector), wildtype (WT) mIGFBP-6 and mutated mIGFBP-6 (A126, A143, A126/143) expressing MDCK cells were conditioned for $48 \mathrm{~h}$. Equivalent amounts of the apical or of the basolateral media were precipitated in acetone, and subjected to SDS-PAGE. Mouse IGFBP-6 
polypeptides were detected by bIGF-II ligand blotting. The figure is representative of 2-4 experiments investigating the mIGFBP-6 mutants in different combinations. 
A

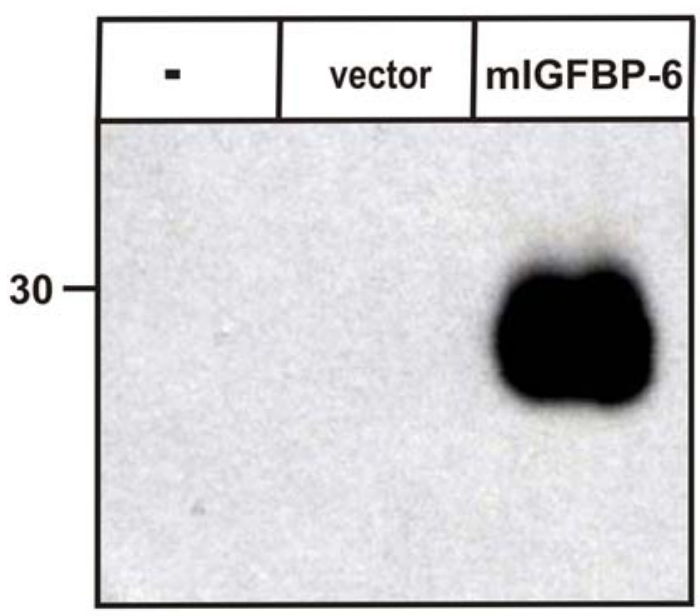

B

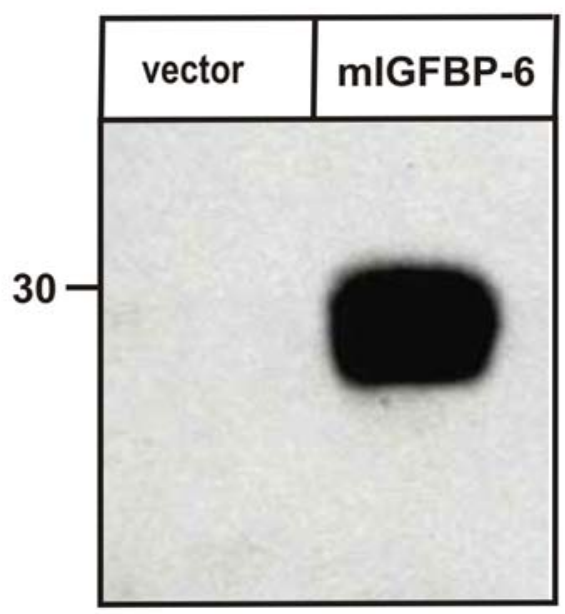

Figure 1 


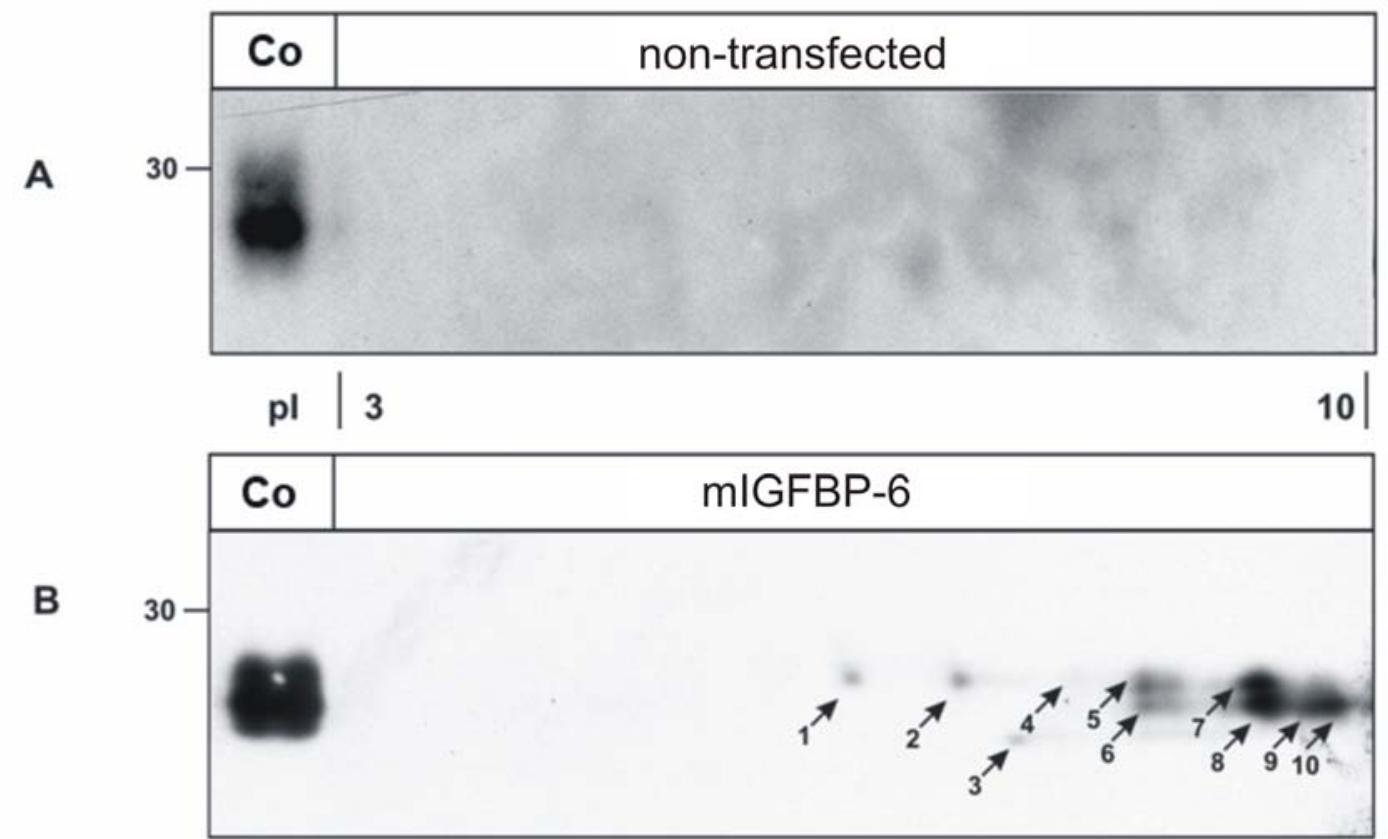

Figure 2 


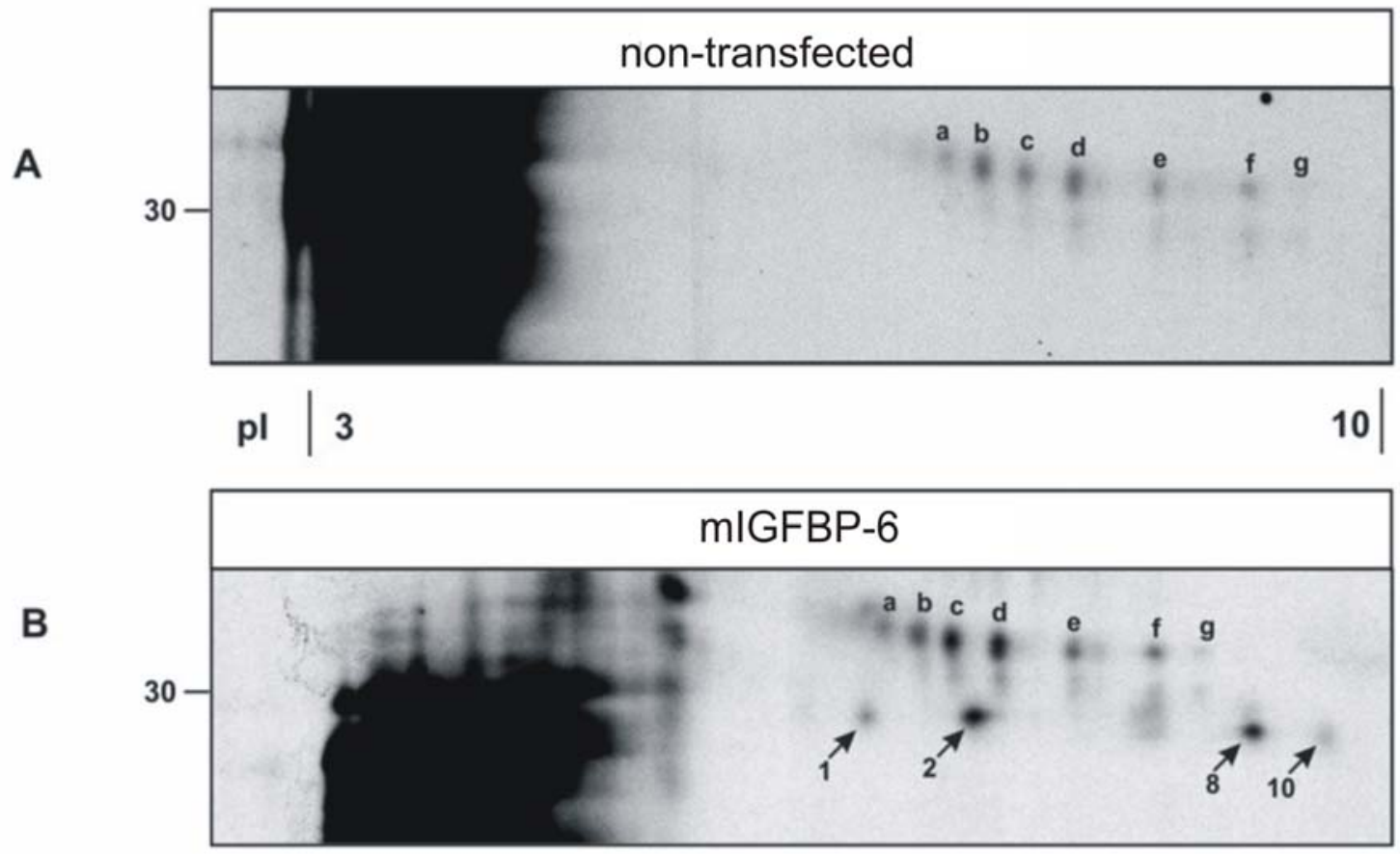

Figure 3 


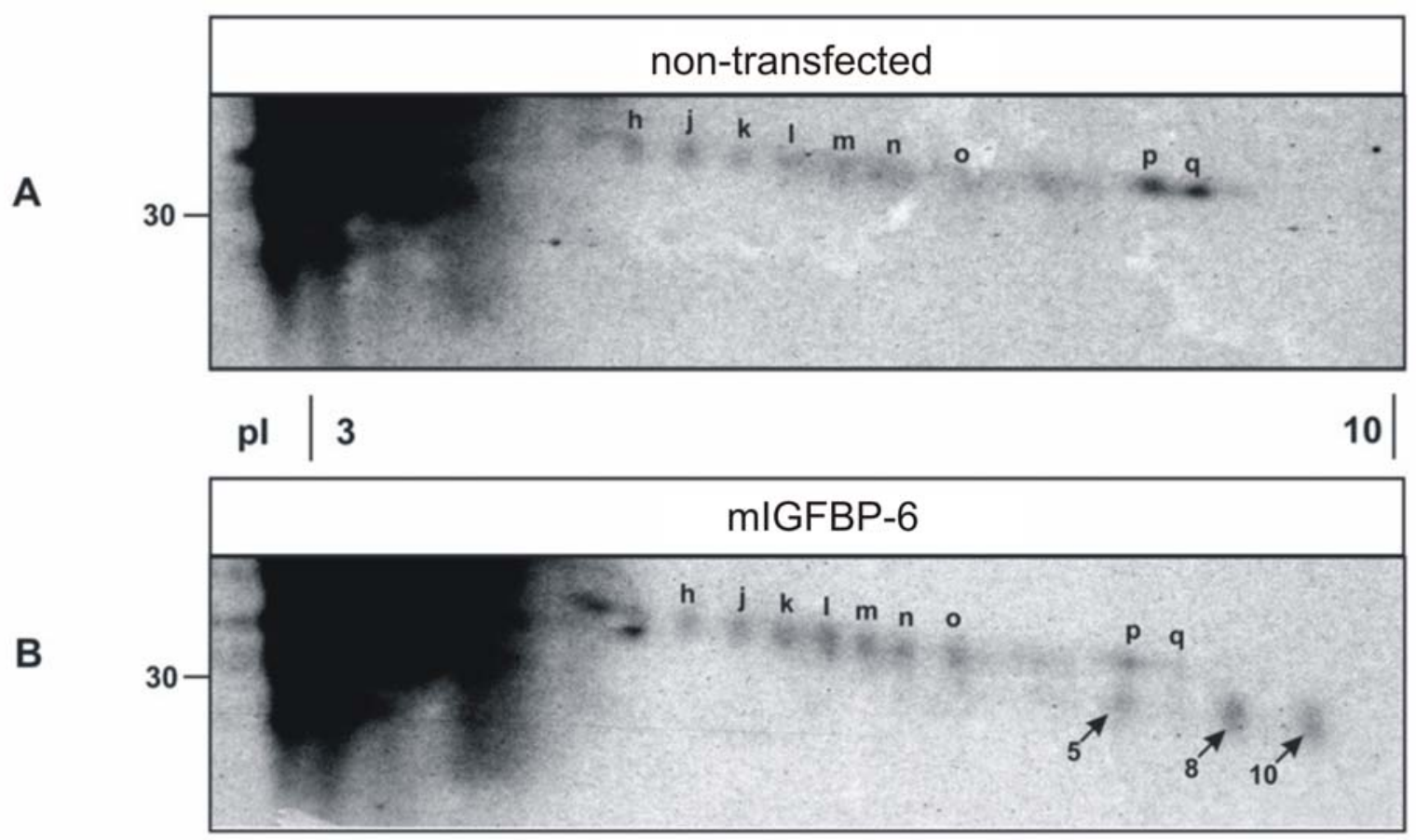

Figure 4 


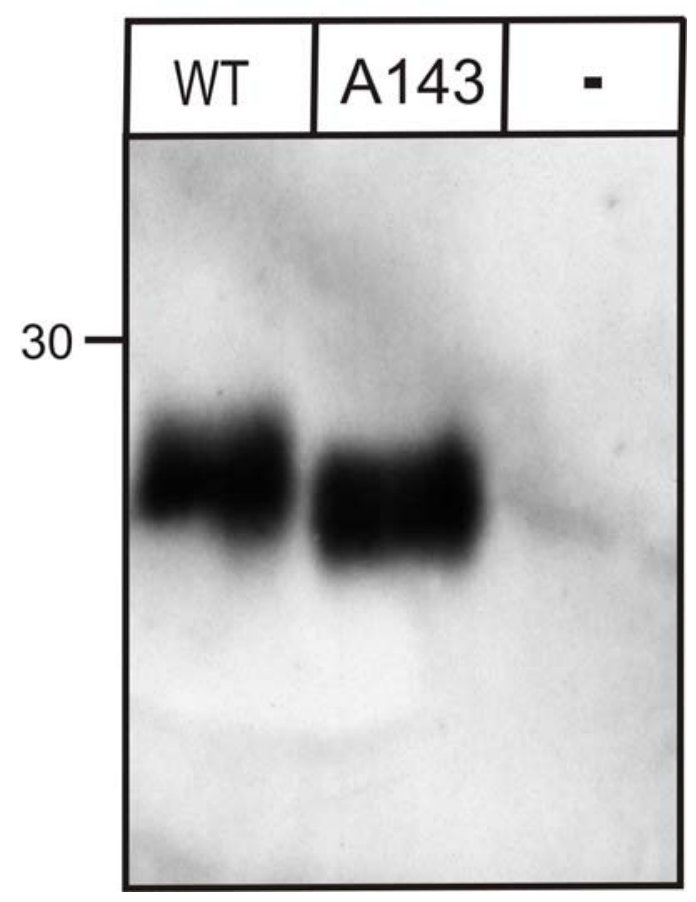

Figure 5 
A

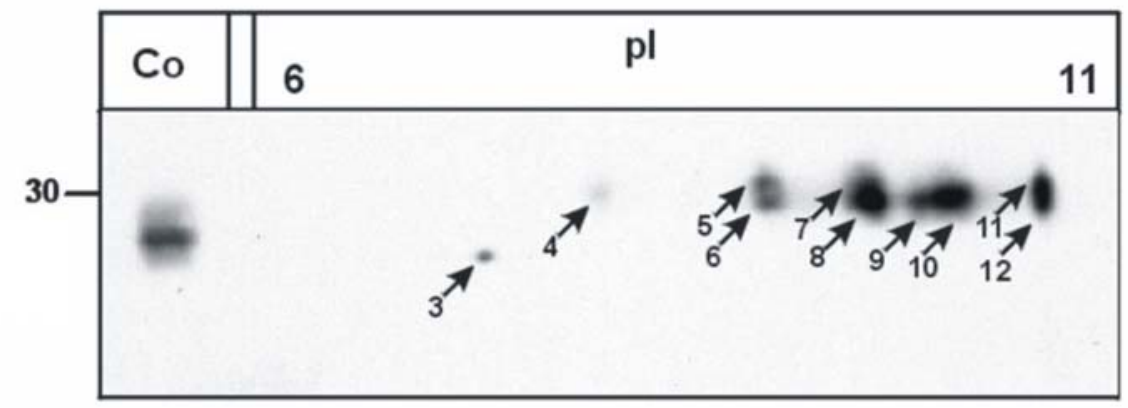

B

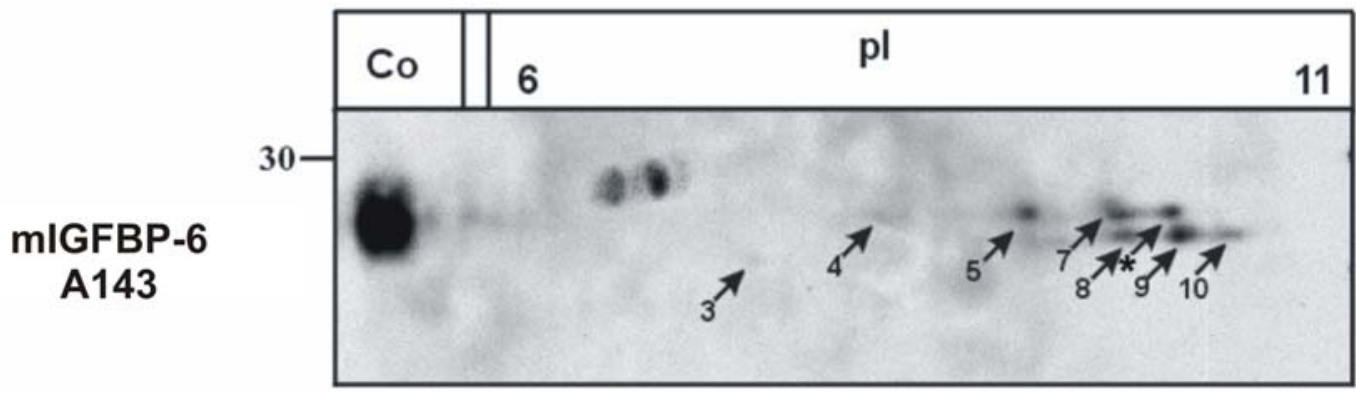

Figure 6 


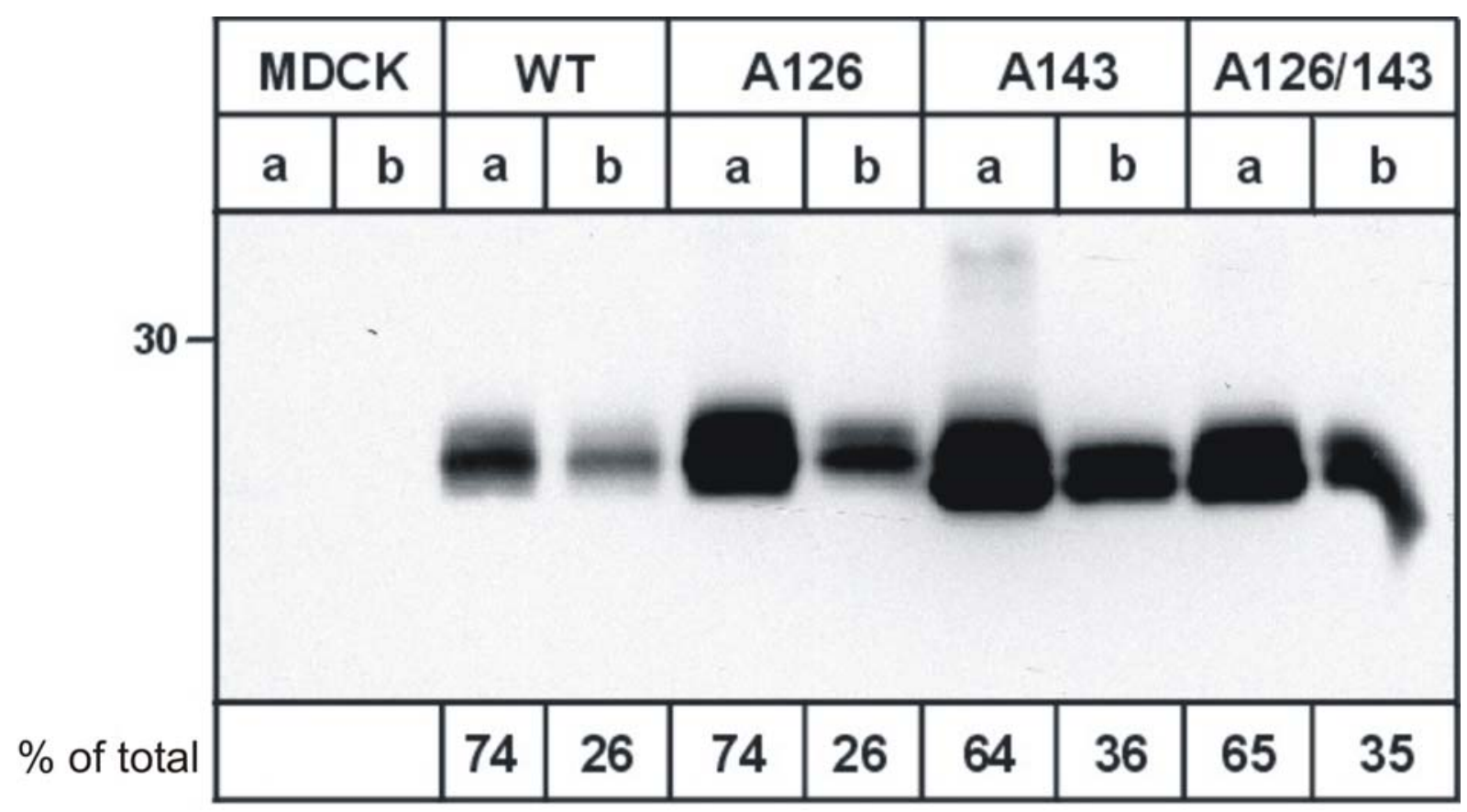

Figure 7 
Table I: Post-translational modifications of mIGFBP-6 isoforms

\begin{tabular}{ccccccccccccc} 
spots & $\mathbf{1}$ & $\mathbf{2}$ & $\mathbf{3}$ & $\mathbf{4}$ & $\mathbf{5}$ & $\mathbf{6}$ & $\mathbf{7}$ & $\mathbf{8}$ & $\mathbf{9}$ & $\mathbf{1 0}$ & $\mathbf{1 1}$ & $\mathbf{1 2}$ \\
\hline kDa & 27.5 & 27.5 & 26 & 27.5 & 27.5 & 26.5 & 27.5 & 26.5 & 26.5 & 26.5 & 27.5 & 27.5 \\
pI & 5.5 & 6.5 & 7.5 & 7.7. & 8 & 8 & 9 & 9 & 9.6 & 9.7 & 10.2 & 10.2 \\
phosphate & + & + & - & - & - & - & - & + & - & + & n.d. & n.d. \\
sulfate & - & - & - & - & + & - & - & + & - & + & n.d. & n.d. \\
O-glycosylation & - & - & - & - & - & + & - & - & - & - & + & + \\
\hline
\end{tabular}

n.d., not determined 